\title{
THE TIMES THEY ARE A-CHANGING
}

\author{
Carol Scarafiotti \\ Rio Salado College \\ Dr. Martha Cleveland-Innes \\ Athabasca University
}

\author{
Come gather 'round people \\ Wherever you roam \\ And admit that the waters \\ Around you have grown \\ And accept it that soon \\ You'll be drenched to the bone. \\ If your time to you \\ Is worth savin' \\ Then you better start swimmin' \\ Or you'll sink like a stone \\ For the times they are a-changin' \\ By Bob Dylan
}

\begin{abstract}
Higher education is engulfed in change. At the same time that institutions of higher education are endeavoring to transform themselves by integrating information and communication technologies into curriculum delivery, student profiles are changing. Low income-ethnic populations are among the fastest growing segment of 18-24 year old students; male enrollments are lagging in comparison to female; and the "digital natives" have arrived. Also, as the Internet provides students with access to a myriad of global educational opportunities, the potential for serving virtual foreign students increases. These changes present challenges and opportunities to institutions of higher education, which strive to serve their constituents through fully online and blended learning formats and aspire to extend education to new markets as well. This paper raises implications for online learning related to changing student populations. It presents two fundamentals crucial for ensuring student success, as well as, access in an online environment. Finally, it recommends two change strategies.
\end{abstract}

\section{KEYWORDS}

Access, Learners, Digital Natives, Institutional Transformation

\section{FROM ACCESS TO CHOICE: BACKGROUND FOR THE MOVE ONLINE}

Access to education has been and remains a primary driver of the distance learning movement. The potential of online learning to enhance access to education is primarily determined by the learner's circumstances [1]. Online learning's predecessor, distance education, has been applied to several situations in which access to education is problematic. 
The first situation is one of sparse population - and occurs where the community of learners is spread over a wide geographical area. The fledgling University of the Arctic is an example of a response to this situation.

The second occurs when a very large population has access to a limited number of "seats" in conventional educational institutions. Consequently, mega-universities, distance teaching universities with 100,000 students or more, have developed. Examples of mega-universities are Indira Gandhi National Open University (IGNOU), with an estimated 500,000 students and the Open University of Hong Kong (OUHK), with over 400,000 students. In both of these cases, the learner's physical environment presented a need that online learning could address.

The third situation deals with adult learners whose complex lives restrict their opportunities to access education through traditional pathways. This profile includes but is not limited to full-time employees, full-time parents, family caregivers - those who need the convenience and flexibility of learning and studying at times and places that work with their schedules.

And now with the ongoing evolution of digital communication tools that students use in their daily lives, a fourth situation is emerging. Many of the younger learners are not so much seeking access to education as they are a preferred way of learning, learning that aligns with the information age skills they have acquired [2].

\section{ENROLLMENT TRENDS AND UNDERGRADUATE DEMOGRAPHICS}

Currently, in North America, all four of the above mentioned factors will continue to create a demand for new learning modalities. Higher education's enrollment projections and changing student demographics listed below reveal that more needs to be done to provide access; access that has not been uniformly available, geographically, or socially through traditional post-secondary education.

- Overall, higher education degree-granting institutions will continue to experience enrollment growth, with a 19\% increase between 2000 and 2013, or from 15.3 to 18.2 million according to The National Center for Educational Statistics (NCES) Projections of Education Statistics 2000-2013. This growth will be characterized most by increasing numbers of 18-25 years olds, whose numbers will expand by $22 \%$ between 2000 and 2013. In comparison, enrollments of students 35 years and older will increase by only $2 \%$ [3].

- It is predicted that enrollment growth for female students will outpace that of men, $21 \%$ compared to $15 \%$. The same forecast shows an increase in full-time students of $22 \%$; in part-time students, $13 \%$; in undergraduate students, $18 \%$; in graduate students, $19 \%$; in public institutions, $18 \%$; and in private institutions 20\% [3].

- Predictions of enrollment increases do not and will not apply equally across the states. According to the U.S. Census Bureau, the ten most populous states as of 2004, presented in rank order, are: California, Texas, New York, Florida, Illinois, Pennsylvania, Ohio, Michigan, Georgia, and New Jersey. However, the states in the top ten list differ when viewed by highest percent of population change. California, New York, Illinois, Pennsylvania, Ohio, Michigan, and New Jersey drop to lower positions and are replaced by Nevada, Arizona, Colorado, Utah, Idaho, North Carolina, and Washington [4]. A similar view from the Society for College and University Planning (SCUP) indicates that over the next 10 years, 17 states, located mainly in the West, will experience more than 
10\% growth with traditional 18-24 year olds and likewise that "seven rust belt" states will experience lower growth in both traditional and nontraditional student populations [5].

- Higher education's undergraduates will continue to be more heterogeneous as viewed from the data in the NCES report, The Condition of Education 2004. Over the past ten years the percent of white students has decreased, while that of other racial/ethnic groups has increased. "Combined, minority students represented nearly a third of all undergraduates in 1999-2000, up from about a quarter in 1989-90" [6]. Watson Scott Swail, president of the Educational Policy Institute in Washington D.C., indicates that by 2050 the $18-24$ year old cohort will be predominately of color and by $2100,50 \%$ of this cohort will be Hispanics and Asian Americans [7].

- Students are incurring more cost in their efforts to attain an education, and their ability to manage the cost of higher education and institutions' ability to support first generation and low income students will be factors in determining completion results. According to "Paying for College, Changes Between 1990 and 2000 for Full-Time Dependent Undergraduates,” college prices and financial aid both increased during the 1990s, and the increases in tuition and fees outpaced both inflation and growth in the median family income. The same period saw an increase in the percentage of full-time, dependent undergraduates who received financial aid (consisting primarily of grants, student loans, or both) [8].

- The trend of students who work while attending school is likely to continue. In addition to working adults who attend college, an increasing number of college students in the 18-24 year old category work either part-time or full-time. Over the last 10 years the percentage of students working full time increased seven percentage points [9].

- The Society for College and University Planning (SCUP) indicates that it is taking longer for students to attain degrees and not everyone who starts attains their goals. Only 55\% of students who start college complete it within six years [10].This is the new reality for students across age groupsmultiple role learners who juggle busy lives. This new reality will continue to affect time to completion and completion rates as workload issues become more likely to interfere with studying.

- The undergraduate student body is mobile with $59 \%$ of undergraduate students attending more than one college [10]. Most likely the expansion of fully online education will increase the number of such mobile students who will demand more efficiency transferring credits from institution to institution.

\section{THE ARRIVAL OF THE “DIGITAL NATIVES”}

Higher education is facing changes not only in student demographics, but also changes in students' skills and approaches to learning. Marc Presnky's often quoted phrases "digital natives" and "digital immigrants" illustrate the differences between the students who grew up with technology and those older students and faculty members who had to develop new skills in order to assimilate into the digital world. These terms ring truer than ever today [11].

The May 2005 edition of Wired features, “digital native,” Emma Maree Urquhart of Inverness, Scotland, describing her as a "hack addict" who wrote a best selling fantasy novel about teens trapped in a virtual reality game. Upon completing the novel, she searched the Internet for publishers and succeeded in getting her novel published locally as well as in the UK and the USA. The BBC is considering a Dragon Tamers TV series, and Warner Brothers and Miramax are dangling film offers. In the meantime, 13 yearold Emma hired her dad as her agent [12]. Emma represents those students who, with each decade, become more eminently skilled with technology than their predecessors. And more like Emma are on the way. In an article in the Arizona Republic, June 2005, the Education Department reports that almost one in four children in nursery school has used the Internet. 
As of 2005, 18 to 24 year olds born between 1980 and 2003, referred to as Millennials, NetGen, or the YGeneration, are enrolling or are enrolled in institutions of higher education. They are the generation that takes technology "for granted." For them, computers, the Internet, cell phones, personal digital assistants (PDAs) and digital cameras are merely tools and devices used in everyday life. They are sophisticated consumers who want options, customization, the ability to "try before they buy"[13].

The Educause eBook Educating the Net Generation, edited by Diana and James Oblinger, describes these students as "visually literate," uniquely able to "weave together images, text, and sound in a natural way." They are able to piece information together from multiple sources. They prefer inductive discovery, and because of their ability to shift their attention rapidly form one task to another and to respond quickly, they expect rapid responses [14]. This group will adjust rapidly to online learning environments and welcome to opportunity to use well-developed competencies in the learning environment. Likewise this group will be frustrated by outdated online learning milieus such as text heavy online courses which merely replicate the content in a textbook or by faculty who refuse to use technology enhanced communication in their courses.

\section{GLOBAL STUDY AND TRANSNATIONAL HIGHER EDUCATION}

While prospects abound for institutions to adapt the learning experience to the mind set of the digital natives, equally interesting opportunities exist in the global education market. Global competency is seen as key to a strong citizenry and competent business leaders, yet less than $1 \%$ of college age students travel to study abroad. The knowledge, skills and attitudes required to appropriately maneuver an international, multicultural and multilingual world are best gained through direct experience with people of other cultures. Technology offers the opportunity for post-secondary institutions to provide students crosscultural experiences using information and communication technologies linked to cross-cultural communities. Recently, the American Council on Education [15] partnered with the AT\&T Foundation to offer an awards program that recognizes institutions using technology for international study at the undergraduate level. This version of online education is designed to enhance undergraduates' international learning at U.S. post-secondary institutions.

Also available is the more challenging opportunity for transnational education in developing nations. "We are at the beginning of the era of transnational higher education, in which academic institutions from one country operate in another, academic programs are jointly offered by universities from different countries, and higher education is delivered through distance technologies," claims Philip G. Altbach, Director of the Center for Higher Education at Boston College [16].

In the current global education marketplace, an average of 2 million students study outside of their home countries. However, a market of 2 million students pales in significance when considering that developing countries contain half of the world's students and lack the capacity to meet the demands of these populations. Consider China, where currently eighty-five percent of its college age cohort is not served by existing Chinese universities and colleges. Table 1 below shows the ten most populous countries by 2010 [17]. 
Table 1: Countries Ranked by Population: 2010

\begin{tabular}{lr}
\hline Rank Country & Population \\
\hline 1 China & $1,347,563,498$ \\
2 India & $1,155,011,202$ \\
3 United States & $309,162,581$ \\
4 Indonesia & $258,824,837$ \\
5 Brazil & $195,579,661$ \\
6 Pakistan & $179,592,311$ \\
7 Bangladesh & $159,765,367$ \\
9 Nigeria & $145,032,482$ \\
10 Jussia & $140,771,044$ \\
& $127,194,656$
\end{tabular}

The availability of technology to make online learning accessible to developing countries continues to increase. IT Facts indicates that (according to the Chinese government), over one hundred million Chinese people are using the Internet, ranking China (among global Internet populations) second to the USA with 135 million users. Likewise, India with 25 million internet users is expected to grow to 100 million by 2007-08 [18].

As cell phone technology proliferated to developing countries where the infrastructure did not exist for telephones, so it appears will wireless technology, making it possible to connect with hundreds of thousands of potential students who previously were locked out of education. The following statistics from census data reveal that a global move to wireless and broadband is underway:

- Wireless data access experienced a 29\% increase in global wireless Internet users in 2004.

- Fifty-four percent of the general adult population in Japan has wireless Internet access, far ahead of runners-up South Korea, with $28 \%$, and the US, with $20 \%$.

- Of the 12 countries studied the bottom three were Russia, with 2\%, Brazil, with 3\%, and India, with $4 \%$.

- Today there are more than 150 million broadband subscribers worldwide, according to IMS Research.

- More than 51 million have signed up for service since the beginning of 2004.

- The number of broadband subscribers will surpass 400 million in 2009 [18].

\section{IMPLICATIONS FOR ONLINE LEARNING IN HIGHER EDUCATION}

Overall, the market for online learning continues to be strong. Students from many of the groups described thus far will continue to seek more convenient, flexible learning opportunities, as well as learning experiences that correspond with their digital skills. Additionally, students in states and countries where access to those traditional on-campus seats is becoming more competitive will look for cost effective online learning opportunities. Below are questions/implications for consideration by both higher education institutions currently involved in online learning and those considering its potential. 
1. Does the predicted enrollment increase in traditional aged students present greater opportunity for a blended approach to online learning? And likewise, will the $2 \%$ predicted growth in students 35years and older result in fewer enrollments in fully online programs?

2. What should institutions do to capitalize on the continuing robust female market for online learning?

3. Could a new approach to online learning or new programs appeal to the declining male market? For example are there implications in data such as UCLA's Higher Education Research Institute (www.gseis.ucla.edu/heri/heri.html) report where during their last year of high school approximately 23\% of freshmen men (now enrolled at UCLA) played video games 6 or more hours a week while $28 \%$ spent 6 or more hours on homework?

4. How can institutions in states where enrollment declines are predicted offer online programs with a national and international appeal?

5. As more low-income and first-generation students seek educational access through online learning, what kinds of support need to be in place to ensure their success?

6. Can able and ambitious high school students be a new market for online higher education?

7. Do existing online courses and programs reflect the level of sophistication expected by digital natives and if not, what needs to be done in order to attract and retain these students? Is the online technology infrastructure up-to-date and adequate to meet the expectations of the digital natives?

8. What approaches are needed to encourage faculty members to incorporate new competencies such as visual literacy into the learning experiences that they provide?

9. The global market for online learning appears to have tremendous potential for those institutions able to provide virtual affordable educational programs. How can higher education institutions partake in this market? What are the characteristics and components of successful online transnational programs?

10. What is the responsibility of institutions involved in online learning with the issue of national and international transfer of credits?

\section{TWO TRANSFORMATIVE ONLINE LEARNING FUNDAMENTALS}

\section{A. Support for Students Learning Online}

Armed with the awareness of the changing social context, higher education institutions seeking the integration of successful online programs must develop the 'soft' methods of administrative structure, organization and process support-efficiently and effectively-so that offering increased access will also ensure entry to a satisfying and successful education—not just availability.

While higher education has successfully provided support for learners for years, a number of things must now be considered as education delivery moves online. NASPA, the National Association of Student Personnel Administrators in the US, suggests that the distance learning student population needs different support services provided in imaginative ways. It is also likely they will need more support because, at least for those totally online and at a distance, there aren't even the informal structures or campus rhythms to guide them. This means there has to be innovative extensions of what is done on campus and unique offerings for learners attending at a distance. According to the Western Cooperative on Educational technology (WCET), all students deserve access to a full array of student services [19]. Until these are provided, it is unrealistic to expect the same levels of student success and retention between on-campus and the 'new' version of 'offcampus' (online) courses. Consider this-distance students are essentially commuter students who use a different vehicle (e.g., Internet vs. automobile or bicycle) to arrive on campuses. Additionally, today's students participating in all methods of delivery expect services to be available at a time and place convenient to them. In all cases, this is readily achieved by putting services online. 
There is a difference "between providing cyber-services and creating virtual communities" [20] for students, particularly for students who fall into this new category of 'off-campus.' Those studying and engaging the campus through computer networks need not only digital information and access to administrative services, but also a sense of attachment and belonging to the larger institution. Technology provides improved access to courses and services; critical to the provision of a satisfying student experience the development of a campus community that embraces both the physical and virtual campus.

The movement of learner support services to online environments has much momentum. In fact, this transition is causing many institutions to rethink their entire service delivery system. This could add tremendous value to student support, as long as it is realized that the support required to help students adjust to working online must be added; it cannot be assumed that students are well prepared to do so. It is this transition to working online that is the subject of research by Garrison, Cleveland-Innes and Fung [21] identifying the second crucial fundamental: a 'new role' for learners in online education.

\section{B. New Role for Online Learners}

Institutions need to be proactive with support as learners adjust to the online environment. While not all learning activities involve online learning, it is likely that, in the near future, a portion of all learner activities will involve working online.

"In a global society based on expanding knowledge ... health as a civil society and its economic competitiveness, as well as the success of individuals ...., will hinge on having the best possible education and access to lifelong learning opportunities. Around the world, online learning - the use of digital networks to deliver and support learning opportunities-has emerged as a powerful and transformative means to meet these learning needs, as well as to extend and enrich traditional modes of instruction, at the post-secondary level.”

Adapted from the Advisory Committee for Online Learning [22]

This prediction applies equally to all western, industrialized nations. From the perspective of the individual, learning online requires the development of competencies in the role of 'online learner.' As a new social role, the pathway to competence will occur over time as the role becomes normalized, or 'usual.' In this early stage, online communities will contribute to the socialization process for those engaging in this new role.

'Role' is used here as a sociological construct, defined as a collection of behavioral requirements associated with a certain social position in a group, organization or society [23]. At its most general level, role expectations are dictated by the social structure. Individuals who engage in the role are guided, through a process of socialization, to appropriate role performance. Socialization then refers to the "process by which people learn the characteristics of their group ... (and) the attitudes, values and actions thought appropriate for them” [24].

Under conditions of long-standing roles, individuals engage in 'role-taking' behavior, where observation and mimicry of role models allow those new to the role to 'practice' appropriate role behaviors. 'Role making' occurs as individuals construct aspects of the role with their own individual meanings and satisfying behaviors attached. This occurs under social conditions where such individual autonomy is allowed. It also occurs where role models are not readily available, and construction of the role is required. 
Such is the case for becoming an online learner. An adjustment from the more generalized role of learner, the responsibilities and requirements of working online are not readily apparent to those new to the role. The transition to, and adjustment in, the role of online learner, is part of the current social climate in online learning. While maintaining the usual expectations and privileges attached to the role of learner, online learners add such things as:

- knowledge about, skill with and acceptance of the technology,

- new amounts and modes of communication with instructors, peers and administrators,

- increased levels of learner self-direction, and

- a new 'place' for learning in time (anytime, usually determined by the learner and their life circumstances) and space (anywhere, dependent upon equipment requirements).

Institutional support services need to provide a vision of what counts in this new role, and offer assistance, information and guidance during the adjustment process. As individuals are exposed to new experiences and obligations in online environments, identity with the role of online learner will emerge. The definition of role, according to externally defined requirements, provides the structure within which an individual identifies him or herself. Role identity acquisition is part of the individuation in the experience of working online. Each online learner engages in the experience of learning online and the process of role taking and role making occurs concurrently within the learning experience.

The context within which this role adjustment occurs is also undergoing change. In other words, the adoption of online education can act as a catalyst for institutional transformation on many fronts, aligning institutions with requirement of a new social order [25]. This highlights the depth and pervasiveness of change occurring in post-secondary education; awareness and action are an institutional imperative in higher education.

\section{STRATEGIES FOR RESPONDING TO CHANGE}

The integration of online education-replete with the structures, philosophy, roles and outcomes appropriate to the delivery method-into higher education institutions, and the intended transformation based on this action, will not occur without specific, strategic action [26].

\section{A. The "Hedgehog" Concept}

Leaders from successful online eColleges and universities argue that a critical first strategic action involves a clear understanding of the purpose behind the proposed transformation to online learning and its relationship to the institutional mission. A 2005 study of successful Internet-supported learning institutions conducted by the Alliance for Higher Education Competitiveness indicates that a top factor correlating with degree of success is "consistency of Internet-supported learning with the institutional mission." "To successful institutions, Internet-supported learning is an opportunity to reconsider the intersection of mission and student service and to create an improved educational product"[27]. In other words, the type of online learning programs provided should align with the rationale for providing it as well as with the culture of the institution.

An equally helpful insight on commencing institutional transformation comes from Jim Collins, author of Good to Great. His study of companies which transformed themselves from "good-to-great" discovered that their leadership had an innate understanding of the company culture from three viewpoints and that this understanding guided the company's strategy. He uses Isaiah Berlin's metaphor of the Hedgehog and Fox to illustrate the power of this understanding. Hedgehogs "simplify a complex world into a concept that guides everything” while foxes' efforts are diffused and scattered as they frequently change their 
tactics to meet the circumstances [28].

Applying the Hedgehog concept to the development on an online learning strategy requires first that the institution's leadership answer three questions in relationship to the online learning initiative.

1. What drives the institution's mission? In answering this question it is important to assess the source of the culture's passion. For example, is the institution excited about extending educational access to working adults? Is it institution passionate about improving learning?

2. Where can the institution excel? Determining what the institution currently does best is a good starting point. For example, is the institution renowned for providing programs in high demand areas? Is it noted for its extensive technology infrastructure?

3. How can the institution sustain the initiative? The question is about what drives the institution's economic engine and what effect that has on the initiative. For example, it will be important to understand the cost of online learning as part of the business model and benefit to the college.

Institutions positioning themselves in the online learning marketplace, while considering changing student demographics, would do well to take the time to clarity and understand their "Hedgehog" concept. Once the "hedgehog" concept is understood, the institution is ready to begin mobilizing the campus to initiate the change.

\section{B. Mobilizing the Campus}

The institutional change required to embrace online delivery is comprehensive and integral. The move to blended and online delivery, with the required student support, carves out a 'new deal' in higher education, where student needs become a central focus - all the way from accessible and open admission and transfer credit arrangements to online special interest groups providing social interaction so important to young adults in higher education.

These changes challenge many central premises that support the 800 year history of higher education. The changes require that administrative and academic staff reposition their roles in light of a new role for students. These adjusted roles and ways of doing business mean adjustment and growth on the part of all involved — change of a magnitude unprecedented in the history of higher education. Gardner [29] points out, "little systematic account is taken by faculty members, or university administrators and governing boards for that matter, of how today's undergraduate students prefer to learn" (p.24). Most traditional universities use a pedagogy that is steeped in the past and have failed at large-scale integration of the full potential of technology. He further suggests that it is possible to explain but impossible to defend an "institutional hesitancy in responding to distance learning possibilities and related issues bearing on the time, manner, and place of the teaching function, including the age and other changing characteristics of the student body"(p. 24). Most importantly however, technology provides an open learning environment in which student are active learners and consumers of educational services.

At the same time, faculty are resisting the required responsibilities to make the transition to technologically mediated teaching based on the increased workload demands and the limited technological infrastructure currently available [30]. The development of a new role for students in higher education will not emerge without concomitant changes to the complementary role of faculty. "It is the faculty that do the actual teaching, and convincing them of the value of a new and unproven delivery method is a formidable challenge [31, p.20]. 
Evidence of the success of the delivery method and its increasing implementation is now available. This evidence must be communicated to faculty, in disciplinary language they are familiar with. Social change in self-governed, disciplinary based institutions requires multiple activities at all layers of the institution; success requires a central imperative to change and support from leadership, "vision creation, consultative design and collaborative action” [32]. A complex system of emergent, dynamic and stagnant forces create a kaleidoscopic context within which higher education presents, maintains and creates itself. Never has the requirement for systematic, strategic effort to manage the higher education enterprise been more important.

Strategic planning is a critical response that institutions of higher education should choose in order to address this complexity, in a way that allows for greater control over future activities and direction. In stressing the need for strategic planning, Swenk [33] suggests that "to remain viable and vibrant, institutions must develop new social technologies that allow for much more flexible responses." The challenge is to develop systems, planning, and institutional thinking that enables short-term planning and reaction to emergent demands that are coupled with support for the long-term development of disciplines and quality assurance systems [34]. Strategic planning is the most logical way to address this challenge of online education as a delivery method.

\title{
VIII. CONCLUSION
}

The Sloan Consortium's second annual study on the state of online education indicates that, overall, online education is Entering the Mainstream and that most schools currently engaged in online learning view it as "critical to their long-term growth strategies [35]. Social change in self-governed, disciplinary based institutions requires multiple activities at all layers of the institution; success requires a central imperative to change and support from leadership, "vision creation, consultative design and collaborative action” [32, p. 31]. At the faculty level, institutional requirement supported by grass roots support for knowledge and skill development make the critical combination. Identification of competent change agents willing to champion new directions at the level of more intimate professional and personal relations are key.

Thus, the "changing times" present institutions of higher education with many challenges and also opportunities to meet the needs of students everywhere through some form of online learning. The author's conclude by urging institutions to move forward with their necessary transformations, noting the prescient advice of Bob Dylan.

\author{
As the present now \\ Will later be past \\ The order is \\ Rapidly fadin'. \\ And the first one now \\ Will later be last \\ For the times they are a-changin' .
}

\section{ABOUT THE AUTHORS}

Carol Scarafiotti, Vice President Emeritus at Rio Salado College (a Maricopa Community College), currently serves as Executive Consultant for Online Learning at Rio Salado College. A recipient of the Sloan C Award for Excellence in Online Learning, she is known for her leadership experience in online learning systems. 
Dr. M. Cleveland-Innes is Associate Professor in the Center for Distance Education at Athabasca University. She is an award winning scholar in distance and higher education with an active research and publication program. Current research interests are in the sociology of distance education, disciplinary differences in higher education and distributed learning in the workplace.

\section{REFERENCES}

1. Hugues, J. Supporting the online learner. In Anderson, T. \& Elloumi, F. (Eds.), Theory and Practice of Online Learning, 2004. http://cde.athabascau.ca/online_book/.

2. Frand, J. The information-age mindset: Changes in students and implications for higher education. EDUCAUSE Review 35(5): 16, September/October 2000.

3. Projections of Educational Statistics to 2013. Section 2 Enrollment in Degree-Granting Institutions, National Center for Educational Statistics, 2003. http://nces.ed.gov//programs/projections/ch_2.asp.

4. Ranking Tables for States: Population in 2000 and Population Changes from 1990-2000. Census 2000. U.S. Census Bureau. http://www.census.gov/population/www/cen2000/phc-t2.html.

5. Trends in Higher Education, Demographics. Society for College and University Planning 2: March 2005. Online: http://scup.org.

6. Highlights from The Condition of Education. National Center for Educational Statistics, 2005. http://nces.ed.gov//programs/coe/press/highlights.asp.

7. Swail, Watson Scott. Higher education and the new demographics questions for policy. Change 14: July-August 2002.

8. Paying for college: Changes between 1990 and 2000 for full-time dependent undergraduates, special analyses. Condition of Education, National Center for Educational Statistics. http://nces.ed.gov/programs/coe/2004/analysis/index.asp.

9. Orszag, J., P. Orszag and D. Whitmore. Learning and Earning: Working In College, 2000. http://www.brockport.edu/career01/upromise.htm.

10. Trends in Higher Education. Society for College and University Planning 1: 2005. http://scup.org.

11. Prensky, Marc. Digital natives, digital immigrants. On the Horizon (NCB University Press) 9(5): 1, October 2001.

12. Fantasy, She Wrote. Wired 56: May 2005. http://www.wired.com/wired/archive/13.05 /start.html?pg=14.

13. Tapscott, D. Growing up Digitally: The Rise of the Net Generation, 11. New York: McGraw-Hill, 1998.

14. Oblinger, Diana and James. Is it age or IT: First steps toward understanding the Net Generation, Educating the Net Generation. Educause, 2005. http://www.educause.edu/content.asp ?page_id=5989\&bhcp=1.

15. American Council on Education. The ACE/AT\&T award: Technology as a tool for internationalization, 2003. http://www.acenet.edu/AM/Template.cfm?Section=Search\&section=att\& template=/CM/ContentDisplay.cfm\&ContentFileID=22.

16. Altach, Philip. Can the United States remain the top destination for foreign students? Change: March/April 2004.

17. U.S. Census Bureau. International Database: Updated May 10, 2000. http://www.census.gov /ipc/www/idbrank.html.

18. IT Facts. Online: http://www.itfact.biz.

19. Western Cooperative for Educational Telecommunications. http://www.wcet.info/projects/laap /guidelines/overview.asp\#should.

20. Kretovics, M. The role of student affairs in distance education: Cyber-services or virtual communities? http://www.westga.edu/ distance/ojdla/fall63/kretovics63.html. 
21. Garrison, R., M. Cleveland-Innes, and T. Fung. Student role adjustment in online communities of inquiry: Model and instrument validation. Journal of Asynchronous Learning Networks 8(2): 2004. http://www.sloan-c.org/publications/jaln/v8n2/pdf/v8n2_garrison.pdf.

22. Advisory Committee for Online Learning. The e-learning evolution in colleges and universities: A pan-Canadian challenge. Communication Branch, Industry Canada. Ottawa, Canada, 2005. http://www.schoolnet.ca/snab/e/Agendas/AgendaApril24_2001/6A-ONLIN.pdf.

23. Kendall, D., J. Murray, J., and R. Linden. Sociology in Our Times. Ontario: Canadian Cataloguing in Publication, 2000.

24. Kanwar, M. and D. Swenson. Canadian Sociology. Iowa: Kendall/Hunt Publishing Company, 2000.

25. Oblinger, D. G. and J. Kidwell. Distance learning: Are we being realistic? EDUCAUSE Review: May/June, 31-39, 2000. http://www.educause.edu/pub/er/erm00/articles003/oblinger.pdf.

26. Hache, Dennis. Strategic planning of distance education in the age of tele-informatics. On-line Journal of Distance Learning Administration 1(2): 1998. http://www.westga.edu/ distance /Hache12.html.

27. Abel, Rob. Achieving Success in Internet-Supported Learning in Higher Education, 2005. http://www.a-hec.org/e-learning_study.html.

28. Collins, Jim. Good to Great, 118-119. New York: HarperCollins Publishers Inc., 2001.

29. Gardner, D.P. Meeting the challenges of the new millennium: The university's role. In: W. Z. Hirsch and L.E Weber (Eds.), Challenges Facing Higher Education at the Millennium. Phoenix AZ: The Oryx Press, 1999.

30. Shale, D. The hybridization of higher education in Canada. International Review of Research in Open and Distance Learning 2(2): 2002.

31. Allen, E. I., and J. Seaman. Sizing the Opportunity: The Quality and Extent of Online Education in the United States, 2001 and 2003. Needham, MA: The Sloan Consortium, 2003. http://www.sloan-c .org/resources/sizing_opportunity.pdf.

32. Cleveland-Innes, M., C. Emes and J. Ellard. On being a social change agent in a reluctant collegial environment. Planning in Higher Education 29: 25-33, 2001.

33. Swenk, J. A chaos theory metaphor for strategic planning. In: Cutright, M., (Ed.), Chaos Theory \& Higher Education: Leadership, Planning, \& Policy. New York: Peter Lang, 2001.

34. Kershaw, A. and S. Safford. The Impact of Technology and Student Choice on Postsecondary Education: Plus ca Change. In: Cutright, M., (Ed.), Chaos Theory \& Higher Education: Leadership, Planning, \& Policy. New York: Peter Lang, 2001.

35. Allen, E. I. and J. Seaman. Entering the Mainstream, The Quality and Extent of Online Education in the United States, 2003 and 2004. Needham, MA: The Sloan Consortium, 2004. http://www.sloan-c .org/resources/entering_mainstream.pdf. 